Session 2206

\title{
DESIGNING WITH HISTORY AND TECHNOLOGY The Hop Brook School: a case study
}

\author{
Daniel Davis, AIA \\ Architectural Engineering Technology \\ Ward College, University of Hartford
}

\section{Abstract}

The Hop Brook School in Naugatuck, Connecticut, is a project that blends history with technology. The cost effectiveness that resulted from using the most advanced technologies available allowed the traditional style additions and renovations at the Hop Brook School to be possible. It was not long ago that sympathetic additions to historically sensitive buildings were precluded due to the expense. In this project, however, not only was it possible to provide sympathetic and sensitive additions and renovations but it was done within the limits of an extremely cost conscious public school budget. The remodeled school, which won a 1994 Design Award from AIA/Connecticut and a 1995 Preservation Award from the Connecticut Trust for Historic Preservation, was a successful synthesis of traditional and technological construction techniques and planning principles.

\section{Architectural History of Naugatuck}

The Hop Brook School was originally designed in 1914 by Connecticut's most prominent female architect, Theodate Pope Riddle, at the request of local industrialist Harris Whittemore. In addition to the Hop Brook School, the Whittemore family is responsible for several major contributions to the architecturally rich community of Naugatuck, often employing the best architects of the day. The resulting buildings, though not related to each other stylistically or through the use of materials, provide a variety of experiences and in effect create a small architectural museum within the town.

It is important to understand the architectural heritage of Naugatuck to fully appreciate the architectural and historical obligations of this project. Most of the architecturally significant structures are concentrated around the green. One arrives at the green by traveling across the Bridge, dedicated in 1914 and designed by Henry Bacon, winner of the 1923 AIA Gold Medal. The green, with its pink granite fountain, landscaping and paths, as as the immediately surrounding structures, were all designed by Mead and White, the country's most fashionable architectural firm at the turn of the century.

Constructed in 1892-94, the Salem School faces the green, and visually terminates the major eastbound road into town. On the hill above this building sits the more severely classical Hillside School. Built in 1901-05, it is effectively a temple on an acropolis, overlooking the green. On the east side of the green, opposite the schools, and plar Mead and White designed a small but impressive granite library in 1894. For the narrow site between the library and the Victorian Town Hall they also designed the rather modest as easy to I National Bank (189394). Unfortunately, it was subsequently demolished along with the original Town Hall to make way for a new 
Town Hall. Finally, the brick Georgian-styled Congregational Church was buiit to the north of the green in 1901-03,

A short distance from the green stand two structures designed by architects who were at one time associated with McKim, Mead and White. The shingle style Naugatuck Train Station, built in 1910, was designed by Henry Bacon who worked with McKim in the 1880's and was also responsible for the design of the Lincoln Memorial.. And lastly, the Hop Brook School was designed by Theodate Pope Riddle who was apprentice to and worked with White in the late 1890s on the Hill-Stead House, a residence commissioned by her father, Alfred Atmore Pope,

\section{Theodate Pope Riddle}

Registered in 1910 as Connecticut's first woman architect, Ridule's slyle of architecture developed from her travels throughout Europe, and her knowledge of the Arts and Crafts movement, Refused admission to all-male Princeton, she supplemented her education with private tutors. In addition to the Hop Brook School, other noteworthy projects include renovations to the Theodore Roosevelt Residence in New York City; the Westover School (1909-12), in Middlebury, Connecticut; and in the early 1920s the Avon Old Farms School, in Avon, Connecticut (this project earned her a diploma from the Fifth Pan American Congress of Architects 'for excellence in design'). Her Hill-Stead House, in the historic colonial village of Farmington, Connecticut, is a completely intact Colonial Revival 'country house' displaying her family's world famous collection of French Impressionist paintings.

\section{The Original Hop Brook School Blends Tradition with Technology}

Construction at Hop Brook began in 1914 and the school opened in 1916. The school, rooted in English tradition and the utilitarian Arts and Crafts style, was originally set back from a quiet street with a generous sweep of lawn, and was announced by a tall brick gateway. The main entrance was flanked by a projecting gymnasium/auditorium wing and a separate kindergarten building. The state-of-the-art school was originally equipped with locker rooms, running water, an innovative ventilation system, precast concrete ornamentation, concrete plank flooring, and other advanced building systems. Thus from the onset the Hop Brook School was no stranger to a blending of traditional and technological ideals.

\section{The School Survives, Just Barely}

By 1992, and the 75th anniversary celebration, the school had suffered a variety of unfortunate changes. The original entrance was rendered inaccessible, and a golf course had absorbed the quiet street the school once faced. The fresh air supply ventilation towers, which functioned properly for many years, were removed rendering the original ventilation system ineffective. A portable classroom structure occupied the original entrance courtyard causing the entry to be forced to the rear, through either of two fire stairs. In 1969 and again in 1970, modern additions were placed on the building that were totally insensitive to the original school. In the interior, neglect, decay and energy conservation measures all but obliterated the architectural character of the original school.

\section{Renovations and Additions}

The plan for this project was to remove all previous additions, remodel and restore the original building of 26,000 sq. il., and provide an addition of 27,000 sq. $\mathrm{ft}$. true to the design, character and materials of the original 
building. Fortunately, this approach was fuily endorsed by the building committee, school staff and consultants, and served to save the school from an uncertain future.

But now, the challenge presents itself how do we accomplish all this without spending more than the referendum budget total of $\$ 6.9$ million? Furthermore, after subtracting professional fees, other soft costs and miscellaneous expenses, the construction budget available is really only $\$ 5,9$ million. Fortunately, the team had the assistance of an experienced construction management firm. After many estimates and value engineering studies it was determined to 'gut' the existing construction, leaving only an exterior shell and the interior corridor walls. The additions and renovations were to be designed to appear to duplicate the original construction methods, but were actually done with the inconspicuous use of modern, cost effective building techniques. It is now impossible to distinguish the original building from the new construction.

\section{The Technology}

While the original building was constructed with load bearing block walls, it was not appropriate or cost effective to continue this practice. In the new addition, for planning flexibility and speed of construction purposes a structural steel frame was erected using ASTM A 36 steel. With a structural steel frame, interior as well as exterior walls could be more economically provided with metal studs. Interior walls were typically constructed of 3 1/2" metal studs with a double layer of gypsum board on each side. Exterior walls were of brick with 6" metal stud back-up, an air space and insulation.

The roof structure of the addition was also handled differently than the original building. For cost effectiveness and speed of erection reasons a prefabricated Douglas Fir wood truss system was used. Trusses were designed by professional engineers that accommodated all loading in accordance with State of Connecticut Basic Building Codes at a substantial savings.

The original building's floor system incorporated planks spanning from bearing wall to bearing wall. The addition was constructed with a 2 " deep, 20-gauge, galvanized composite metal floor deck. This deck is secured in place with 3/4" diameter fusion welds and covered with 3,000 psi concrete for an overall thickness of 5 " which eliminated the need for sprayed on fire proofing.

The 75 year old wood windows of the original building were covered with multiple coats of lead paint and were thermally inefficient with single pane glazing and air infiltration problems. The windows had aged and developed some rot and decay. The solution here was to use a highly efficient double pane aluminum window designed to address structural performance requirements, air infiltration, water penetration, condensation, thermal transmittance and forced entry The flames were coated with a siliconed polyester baked enamel finish in a historically appropriate color.

Wood flooring was originally used throughout the building, but only the flooring in the corridors could be saved, refinished and reused. While it would be difficult due to cost to provide a traditional wood floor in the new corridors, an acrylic impregnated wood strip flooring was an available option, This product is comprised of a three ply laminate acrylic impregnated hardwood plywood plank flooring system, with a felt underpayment and finished with maple to match the existing wood surfaces,

The site was enhanced with precast concrete unit pavers which match the building brick and an ornamental aluminum fence reminiscent of the original cast iron fencing that was either damaged or removed. An innovative design was also developed to handle the drainage of the site and sunken court yards. 
All of these new products and modern techniques were used throughout the building in a very inconspicuous and sensitive fashion. The goal of using technology to preserve the character of the original school rather than obliterate it was always a priority.

Technology was also available to the construction manager in the form of a project management software package. This proved to be a benefit for planning, scheduling, project management, budgeting, money management and running "what if' scenarios.

\section{Design Issues}

The two classroom wings, one original and one new, are arranged as double loaded corridors on a north/south axis, enabling ail of the classrooms to take fuil advantage of naturai suniight Corridors are wide to permit easy and rapid passage of students. The common faciities of the school are organized around a perpendicular east/west corridor which connects the classroom wings and forms the new entrance to the school.

Site improvements included a new ball field, repairs to the sidewalks and playgrounds, resurfaced parking areas, an effective golf ball screen, and a brick gateway reminiscent of the original. In addition to saving trees along Crown Street landscape work involved a new boundary fence, more trees and shrubs, two garden-like sunken courtyards and a school sign. Both the playgrounds and bus loading area are now safely segregated from onsite traffic, however the playgrounds can continue to be used for evening event parking. The trash and dock areas have been suitably screened with brick walls and fire equipment access has been provided with a breakaway gate.

The main entrance to the school, half a level above grade, includes a sculptural ramp (meeting ADA requirements) for handicapped access and a flight of steps that creates a formal entry. Inside the main lobby, vertical circulation is immediately available via an elevator that is expressed on the exterior as a clock tower that recalls McKim, Mead and White's nearby Waterbury Train Station clock tower.

Two sunken courtyards treated with brick serve to connect the school with the playgrounds, and allow a floor half a level below grade to be used for classroom space. The cafeteria courtyard permits the students and staff to enjoy meals in an open yet secure environment and brings fresh air and brightness into a cafeteria that is also half a level below grade. The other courtyard creates a secure outdoor play area for the kindergarten children.

The gymnasiurn/auditorium and library/media center anchor the east/west corridor and form the nucleus of school life, creating places for education and entertainment, recreation and rest, large gatherings and independent study. The centrally located administration area was planned to provide a direct visual connection with the entrance and bus area to the south and the playgrounds to the north.

The objective for the library/media center was to provide an essentially cheerful, inspiring, durable and appropriate space incorporating modem technology within a traditional environment. In an effort to link this library to the town library and promote reading and awareness, the names of famous authors have been stenciled on a frieze that encircles the room at 10 feet above the floor, similar to the cornice and frieze that wraps the town library. Like its counterpart the gymnasium, the library/media center is expressed on the exterior as a terminus of the east/west corridor. 
In the classroom wings thearrangement is simple and compact witha combination of large 1,000 sqare feet and smaller 300 square foot classrooms. All classrooms are equipped with 12 foot high ceilings, pendant light fixtures, computers, sinks and storage areas.

Not only was it possible to plan the school and arrange the floor plans on the basis of economy and convenience, it was also possible to make the interior and exterior so attractive that teachers as well as students find it a place of daily pleasure and contentment.

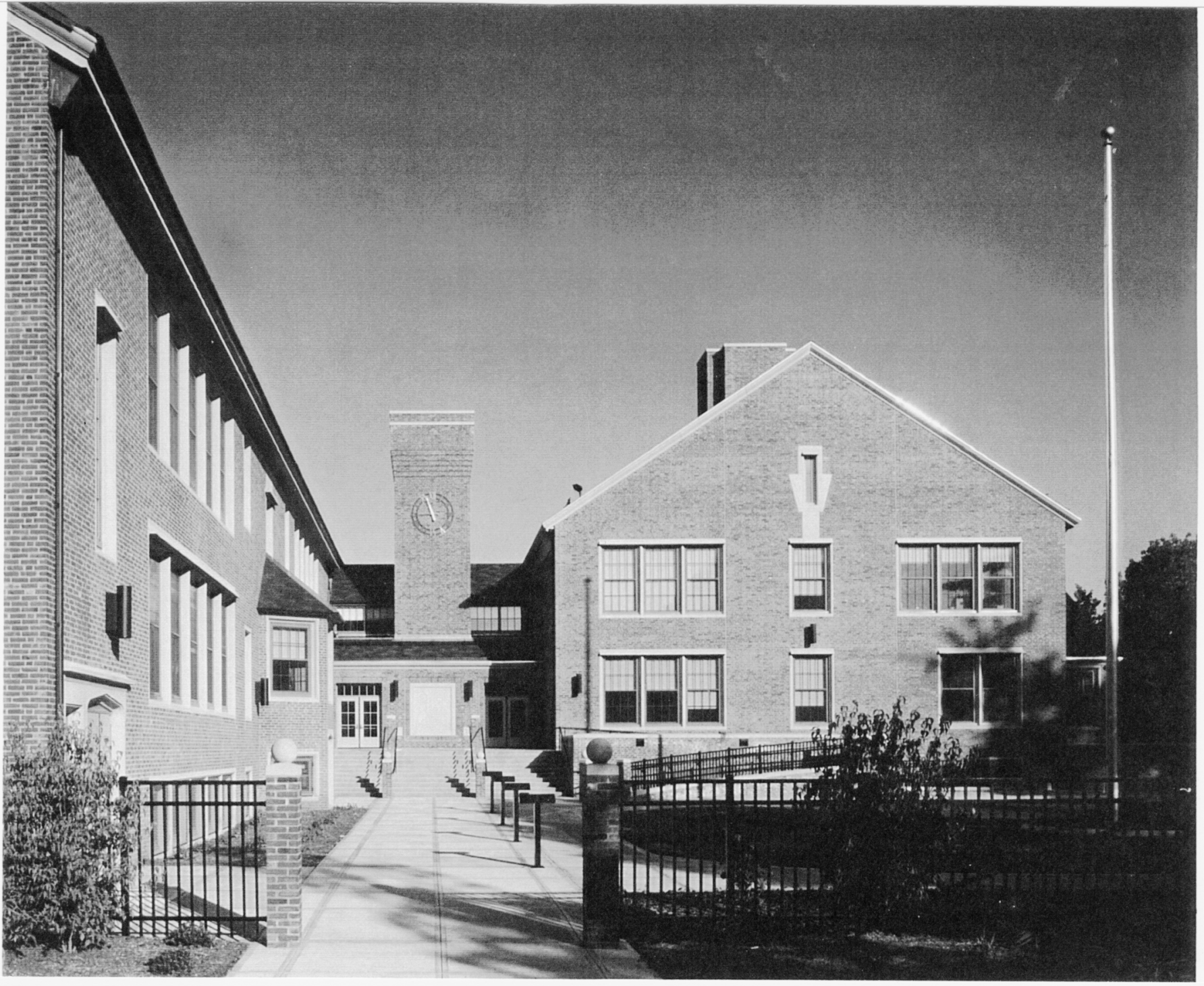

\section{Conclusion}

From a broader perspective, whale society may perceive traditional and technological approaches to be incompatible, I do not. More architects should be willing to allow dissimilar notions such as tradition and technology to exist together. I think architecture should be both old and new, both historic and modern, and both symbolic and fictional. It is from the synthesis of traditional and technological construction techniques and planning principles that the Hop Brook School gains its strength. Before assuming something old has no worth, one has to be open minded and evaluate what exists. In this case, it was easy to recognize the historical significance, integrity, serviceability and quality of the original design and to choose to carry it on. 
In concision, the cost effectiveness that resulted from using the most advanced technology availabie, which included prefabricated wood roof trusses, a structural steel skeleton with metal decking, metal stud masonry back-up, aluminum windows, acrylic impregnated wood flooring, precast concrete unit pavers, and ornamental aluminum fencing, allowed this approach to be possible. It was not long ago that sensitive additions to historically significant buildings were precluded due to the expense and the lack of technology. In this case, however, not only was it possible but it was done within the limits of a cost conscious public school budget. Although the remodeled Hop Brook School has been honored with an award, given in recognition of design excellence, and another award, given in appreciation of historic preservation efforts, the real irony is that no award has been received for the real hero, the technology that made it all possible.

\section{References/Footnotes}

Project was designed by Daniel Davis, AIA while employed by SL/AM Architects, Glastonbury, CT,

Project team also included O \& G Construction Managers, Torrington, CT and BVH Engineers, Bloomfield, CT.

McKim, Mead\& White, A Monograph of the Work of McKim. Mead \& White. 1879-1915, Four Volume, The Architectural Book Publishing Company, 1915-1920, Reprinted in one volume, Dover Publications, Inc., 1990, pp. 219-221.

Stern, Robert A. M., Pride of Place, Building the American Dream, Houghton Mifflin Company and American Heritage, 1986, pp. 23-30.

Wilson, Richard Guy, McKim Mead \& White Architects, Rizzoli International Publications, Inc., 1983, pp. 27,28,36-39.

\section{DANIEL DAVIS}

Daniel Davis, AIA is an Assistant Professor of Architecture Engineering Technology at the University of Hartford's Ward School of Technology were he teaches Architectural Design, Theory and History. He has 15 years of experience as a Design Architect and many of his projects have been published in architectural journals and/or won design awards, Davis holds baccalaureate degrees from Catholic University and Pratt Institute and a second professional degree, a Master's of Architecture from Pratt Institute. 